Ljubiša MITROVIĆ

Faculty of Philosophy

University of Niš
УДК 005.95/.96:378.014

- оригинални научни рад -

\title{
SOCIOLOGICAL MARGINALIA ON THE DEONTOLOGY OF THE VOCATION OF AN EMERITUS PROFESSOR IN THE COMMUNITY OF THE HOMOACADEMICUS IN THE CONTEMPORARY SOCIETY
}

\begin{abstract}
There is no retirement for a true thinker, scientist and revolutionary. Such persons resist the passage of time as long as they are driven by the creative Eros and Promethean ethos of their vocation. Their intellectual odyssey is all but temporarily stopped by physical death, and it is the test of time that will show the true value of their work, which outlives their authors. The true measure of achievement of professors emeriti is how much they have contributed to the advancement of the quality of education and of scientific work of the community of the homo academicus, how much they have increased its innovation potential, and how much they have multiplied the critical intellectual power of the nation they belong to and of humankind.

The paper addresses the sociological, pedagogical, scientific and culturological aspects of being an emeritus professor in the contemporary society. Practice shows that developed and democratic modern societies, academic communities and corporations are more open to the engagement of professors emeriti and the use of their rich pedagogical, scientific and research experience than underdeveloped authoritarian communities, whose political and managerial elites do not have a responsible attitude towards the potential of those who belong to the "third generation". The paper attempts to classify societies according to their relation towards scientific and pedagogical innovations, and the intellectual potential of professors emeriti, and to point to their deontological role in the contemporary university and society. The author puts forward the hypothesis that mature and healthy societies are open towards the innovation potential of professors emeriti, that such societies do not discriminate against such citizens on the basis of their age, and that they stimulate the synthesis of experience and youth in the permanent education of the homo academicus.

Getting elected professor emeritus is not just an honour but also an obligation to serve the scientific community, national culture and mankind.
\end{abstract}

Key Words and Phrases: intellectual capital, human resources, innovations, the vocation and the role of professors emeriti.

\footnotetext{
*1jubisa.mitrovic@ filfak.ni.ac.rs

** Translated from Serbian into English by Vladan Pavlović, PhD, Department of English, University of Niš, Serbia.
} 
Dare to use your reason freely and to teach that ability to others.

Imanuel Kant

Science is not a hard soil to rest on, but a road leading my thirst for knowledge to transcedence, which leads me to wanting even more knowledge...

For a thinking man, espacially for a researcher and a philosopher, a serious examination of things is the condition of life...

When science opens up to somebody, their efforts and hard work become full of enthusiasm and science becomes an integral part of their lives... Science derives from integrity and creates integrity ... It takes courage not to learn in a disintersted manner, and to explore things in a scientific journey. Therefore, the slogan Sapare aude! is still a valid one.

Karl Jaspers, The Idea of a University, 1946.

\section{Introductory note}

It is no concidence that we have gathered here in Athens, at the foot of the Acropolis, because the basis of the European culture is Greek philosophy and panhellenic humanism. This is the birth place and the location of the first academias, the precursors of universities and of the idea of the university and of the humanitatis. It is here that Prometheus stole fire / knowledge from the gods and gave it to peple so that they could keep their homes warm and light their way to the future. This marked a radical turn away from myths towards rational knowledge. Heraclitus, an ancient Greek philosopher and a poet from Ephesus, referred to education as another Sun for the educated.

This Congress is a good opportunity to ask ourselves the following questions: What is the state of education, especially university education, in the contemporary world, what is the role of science and of the homo academicus in social changes, and the duty and the role of professors emeritiin contemporary academic community and contemporary society? What are the ways of enhancing scientific work and education practice at universities, and of renewing the role of intellectuals and the cultural mission of the university for the sake of sustainable development, humanization of society, fostering the culture of peace and emancipation of man. What can be done so that universities can produce top professionals, who would also be the carriers of the idea of the humanitas, i.e. of the idea that people should make progress without losing their social soul in the process?

Our dedication to this and similar topics requires us to keep reconsidering our duties and responsibilities; hence the title of this paper, namely Sociological marginalia on the deontology of the vocation of an emeritus professor in the community of the homo academicus in the contemporary society. 
In order to tackle the topic better, I will first make several remarks on the global social context - the relation between society and university, the crisis of the contemporary world, and the position of the university today.

\section{The crisis of the contemporary society, and the position and role of the university today}

We live in the era of globalization, the emergent world of post-national groups, of a networked society and postmodern culture. Despite these changes, the global society is still not humane and stable. In addition to the processes of technological integration and development, we are faced with the processes of social division, disintegration and subdevelopment of most countries, of many nations and much of humankind. We are faced with a crisis that is both structural and that cannot be resolved within the current capitalist system, which strives to remain predatory and neototalitarian.

Namely, the forces of globalism, through the neoliberal development strategy, strive to renew the neo-colonial and the neoimperial relations in the world, that can be seen in the form of social-darwinization and segregation among social classes and regions, the countries of the world centre, the world semiperiphery and the periphery. It is in this context that regional and global contradictions between the North and the South are widening.

The European Union is turning from a noble project of unification of citizens and nations into a technocratic and plutocratic creation, with an everwidening gap between the North and the Soth, the "Europe of bankers" and the "Europe of workers" (P. Bourdieu). Spurred by the dominant influence of the Anglo-Saxon neoliberal development model, the EU witnesses the process of the destruction of a social state, and is engulfed by the powers of the megacapital, of the money-driven Internationale, and gets reduced merely to an extension of the USA and of the NATO.

Numerous reforms in the form of public policies in the EU can illustrate this very well. For example, the Bologna process, as a process of making education more functionally oriented and guided by a set of unified rules, caters to the logic of class division of labour of European and global corporations, leading to desovereignization of the autnomy of the national education systems and turning universities into commercial institutions for producing people who are highly skilled in a very tiny area and who will serve a one-off purpose on the labour-market. The Bologna reform is also characterized by unequal exchange on the "grey cell" market - the medieval systematic collection of non-Muslim children in Christian populations of the Balkans, practiced by Ottoman Turks, in which a number of healthy boys and young men had to be taken by force to Turkey, converted to Islam and educated for military profession or religious disciplines, has been replaced by brain drain, typically from the poorer South to the richer North. In such a situation, the countries in transition are left without the best professionals who would be the new elite that might unblock the development of such countries. 
In such a context of global relations, the contemporary university, although it has been massively influenced by the third development wave (it istechnologically well networked and functionally integrated), still has all the weaknesses of the contemporary society and is an agent of its convervation rather than of innovation and radical social change.Namely, the university, as the seat of knowledge, should at the same time be the centre of spirutal values and of the critical thought of a nation and of humankind.The university must be at least a step ahead of society so as to be able to be an agent of progress in the contemporary world. Unfortunately, that is still not the case.

A crical evaluation of the basic roles of the university (the educational, the scientific and the cultural / pedagogical ones) faces us with a discrepancy in the accomplishment of those roles in the contemporary social practice. Namely, the educational and scientific rolesof the academia are developing at the expense of the cultural and pedagogical, or, more broadly speaking, of the social and cultural ones. This practice is spreading rapidly, and affects the countries that belong to different areas in the global system. This testifies to the loss of autonomy of the contemporary university and its becoming and extension of the power of transnational corporations and of other alliences of alienated power in the world.

The Anglo-Saxon neoliberal development strategy has brough about a crisis of the identity of the Europen model of the university, and to its emphasized fundamentalist market orientation. Such a university creates professionals primarily for corporate and global market economy, which has lead to the marginalization of social sciences and the humanities and of their gnoseological, pedagogical and cultural power in creating a balanced world-view and the cultural orientations of the young generation.

\section{On the responsibility of social sciences for the development of the university and for social development}

The issue of responsibility of contemporary social sciences and the humanities not only for their own status but for the state of our universities and in our societies must seriously be taken into consideration.

During the last 30 years, contemporary social sciences have been heavily influenced by scientism and analytic philosophy.Contemporary sociology is dominated by the following paradigms: functionalism, neopositivism and the theory of rational choice. Under the guise of being value neutral, numerous disciplines have been instrumentalized by the unbridled corporate and political forcesof the New World Order.

In this situation characterized by disciplinary chaos and disintegrated labour,practitioners within such disciplines seem uncapable to develop an integral approach to the problems of the social development of the world, of humanization of society and emancipation of man.The critical voice of intellectuals seems to have been silenced in the global public (apart from a few notable exceptions such as N. Chomsky, N. Klein, I. Wallersetin,Sergey Kara-Murza, and the recently deceased P. Bourdieu, A. Zinoviev, A. Panarin and M. Marković). 
It seems pertinent here to emphasize the need for the renewal of the critical spirit in social sciences and the humanities, the renewal of the role of philosophy in education and culture, and of the creation of new gnoseological transdisciplinary syntheses through the results of various scientific disciplines and of philosophy.This can potentially lead not only to new discoveries and the formulation of new integral paradigms related to the world, the society and man, but alsohelp the renewal of the critical mission of intellectuals in the contemporary societydominated by mass culture and indoctrination performed by the agents of the "society of the spectacle",i. e. the global media, which realize their cultural hegemony in the symbolic sphere of the spiritual occupation of the masses.

In this context, it should be emphasized once again that the social sciences and the humanities must avoid being apologetic if they want to be considered as sciences and if they are to help the progress and the humanization of society, and the emancipation of man. Through the power of the scientific research carried out within them and and their influence on the development of rational and humanistic criticism, they must act preventively rather than merely react to events taking place.

They must critically evaluate public policies, their consequences and results in social development, as well as research key contradictions in and problems of local communities, national societies and the global system, i.e. of contemporary mankind. At the same time, they must help find new development perspectives for the humankind, and play an active rolein the formulation of alternative projects of sustainable development and democratic governance, as well as help in the struggle for peace in the global world. Should this happen, they would help realize what Jacques Delors said: "One of the primary roles of education is to enable mankind to take control of its own development". In addition, by doing so, social sciences and the humanities would restore their scientific dignity, their humanistic orientation andtheir responsibility in the community of the homo academicus in the contemporary society.

Faced with global problems in the contemporary world, we must ask for how long the owl of Minerva will keep belatedly stating the truth about things in the form of a lament over our destiny, our errors and our follies. Today, when the world is engulfed by the crisis that tears the fabric of our societies and civilization, and that geopardizes its ecological stability and peaceful coexitence of mankind, scientists and intellectuals do not have the right to flee into their ivory towers, to aesthetisize reality, and and to be morally uninterested in such a state of affairs. Quite the contarary, as best informed people deeply aware of various social issues, they have not only the right but also the duty to raise their concerns, to help awaken Prometheus in the struggle for liberation of man and mankind, and to enable new generations to grapple with contemporary social issues. As Montaigne put it, rights belong to those who are alert and who are struggle for them, and no wind will help any sailor unless they know where their ship is headed to!

As Noam Chomsky, the Nestor of Gerenia among contemporary intellectuals, said: "The search for the truth is just one of the tasks of universities.In addition to that, universities must be reposnive to the needs of the young people, 
protect their interests and teach them the knowledge and the skills that would help them act socially, politically and morally in a responsible way toward others. We should primarily enable them to critically evaluate things and to be able to exercise their right to Promethean rebellion and emancipation" (Chomsky, 2016).

So, join us!

Join the movement of awakening and liberating the Prometheus inside peopleand of struggling for liberty. What you can lose in that struggle is the chains holding you back, and what you can restore is the right to use your reason, to walk upright, to have social dignity and to have the joy of being able to participate in making history.

The choice is yours! Future is in your hands! Persist in the struggle for life and liberty!

In order to overcome the crisis, thecontemporary university and the contemporary societymust restore the power of critical thinking to the social sciences and the humanities, and also restore the social soul in the strategies of development and of transition in the contemporary society. If this fails to happen, universities will be reduced to producing morally indifferent "blacksmiths of false progress", and the states will continue to be in the crisis created by neoliberal globalism which has "put the profit above man" (N. Chomsky), and which social-darwinizes the world and paves the way for conflict, for the rise of the political right, and for racism and neofacism.

It is time we realized that the development of education and science is not a goal in and of itself, but should serve social development andpersonal emancipation, including people's active participation in the contemporary world. Albert Einstein's words also seem pertinent here: It is not enough to educate people in their professional field. This will indeed make them a sort of a useful machine, but will not make them all-ronded personalities.It is important that people get a vivid notion of what the things that are worth striving for are. They should learn how to understand what it is that drives people, what drives their illusions and their sufferings.

\section{Some aspects of the deontology of being an emeritus professor in the university community of the homo academicus}

We live in the "third wave" era and in the emergent society of knowledge, in which capital resources are education and science. Consequently, the current division of labour occurs not in the field or in the factory, but in scientific laboratories, and the real competition takes place on the "grey matter" market.In such a situation, it is the countries and the societies that have the most competent professionals in the key sectors of new technologies that the present and the future of our civilization depend on. According to Adam Schaff, the three key sectors in the development of new production forces are microelectronics, genetic engineering, and nuclear energy. 
The new production forces, as a transproductive social power, necessitate new organization of labour and management. They generate new networks of societies, new forms of economic and social integrations and the globalization of the contemporary world. William Gibsonwas right to say that globalization is the future that has started; the problem is that it is still not equally distributed because of the monopoly of the forces of the megacapital. Therefore, we encounter the phenomenon of asymmetric globalization and its implications for social and regional inequalities in the world.

Science and the university are becoming the central force driving technological, economic and social development.K. Marx, as a philosopher, panhumanist and the harbinger of globalization, anticipated this in the $19^{\text {th }}$ century, when he announced the rise of the labour forces related to new technologies in the era of cybercommunism as a postcapitalist alternative in the development of the society of the future. More recently, the importance of science and the new "third wave" technologies has been pointed out byA. Toffler, D. Bell, A. Schaffand M. Kastels, among others.

Having these changes in mind, some researchers have formulated priorities in the development paradigm, namely geopolitics, which dominated in the first half of the $20^{\text {th }}$ century, and then geoeconomy eventually followed by geoculture in the $21^{\text {st }}$ century. The concept of the geoculture is the broadest one - it subsumes education and culture, and, of course, activities of contemporary universities.

Having in mind precisely this shift in the meaning and the role of capital development resources, today's developed societies are fully conscious of the importance of education, science and of highly skilled professionals for development.In that sense, corporations and scientific laboratories alike practice professional competition, highly value the experience and the knowledge of innovators and their capacity for "creative destruction" (J. Schumpeter). Their knowledge serves as the basis on which economies and and societies boost their potential for inventions and development. This is practiced at universities, which have institutionalized professional competitiveness and competenceas a factor of mobility and advancement in the academic community. This has also lead to the institutionalization of the status of professors emeriti at European and world universities.

This represents not simply paying respect to the most creative university professors who have contributed to science and pedagogical practice in the community of thehomo academicus, but also a vital interst of the very universities to use the experience and the knowledge of retired professors.If we do not succumb to age stereotypes, we could say that for a true scientist and a revolutionary, there is no retirement, because science and the Faustianthirst for knowledge are not simply their professional tasks but an element of their life style (K. Jespers). The work and life expectancy are increasing in Europe today. The factors influencing retirement policy of governments are numerous. Nevertheless, the institutionalization of the status of an emeritus professor is very important. Here I will list some forms of their activities and outline the deontology of the position of an emeritus professor. 
The starting point is that scientists cannot be defined in terms of their age or gender. Although in the academic community the advancement procedures are clearly set, being a scientist for a true creator is something inherent and derives from the ontological passion for research, so it cannot be measured formally. Once retired, true scientists continue to be driven by the creative eros they research, learn, publish. Their getting elected emeritus professorsrepresents not just an indicator of the respect of the academic community for what they have done, but also additional responsibility to use their knowledge, pedagogical experience, and their scientific authority,to enhance the organization of scientific and educational work, and the modernization of the university management system.

One of the tasks of contemporary science, and especially of sociology of science and education (and of contemporary elitopedagogy) is to analyse all the aspects and preconditions of being a scientist and a university professor, and especially of being an emeritus professor in the contemporary university community and in society.

Staring from the above-mentioned roles of contemporary university, professors emeriti can: a)enhance the organization and the quality of teaching especially at the master, doctoral and post-doctoral levels;b)introduce young scientists into the methodology of scientific research, especially within multidisciplinary and transdisciplinary projects; c)enhance the organization of university work and management; d)broaden international interinstitutional cooperation in education and science, and in the transfer of new education technologies;e) help the renewal of the Promethean critical mission of the universities, of scientists and of intellectuals in the development of an informed and active public, and the creation of alternative ideas and projects of sustainable social development; f) enhance the culture of peace and the development of mankind based on solidarity.

These and similar issues require the voice of professors emeriti to be heard so that they could use the authority of their arguments, their philosophical and humanistic wisdom to inspire young generations in the struggle for a new society, because true scientists are neither morally indifferent reserachers nor supporters of the existing order.They are always on the lookout for new possibilities, alternatives and choices, thus paving the way for the engagement of new agents of social change in the struggle for a better, more free and more humane world. Professors emeriti thus have a broader social and humanistic mission in the national and the global society.Their voice should to be heard when it comes to the ecological survival of the planet, sustainable development of the contemporary world, the current social crisis and the possibilities of overcoming it, the struggle for just relations and peace in the world. This is all the more important nowadays because of rising regional and social inequalities, of the rise of the political right, of neofacism and of terrorism in Europe and in the world.

It is in this context of the global problems in the contemporary world (ecology, poverty, hunder, epidemics, terrorism, conflicts, criminal etc.) that our universities and their elites - distinguished scientists, intellectuals and professors 
emeritimust be sensible to the needs of the young educated generation which tends to be unemployed and marginalized. We must find ways of integrating them into the system, which brings us back to the key issue of the character of the current system which generates crisis, which is a structural and a "long wave" one, and which cannot possibly be resolved within the current predatory system.

We therefore need new research into alternative development models, which necessitates the help and the responsibility of the social sciences and the humanities, and the synergy of the best results of all sciences and of contemporary philosophy. Once united in scientific research and showing solidarity in the struggle for a new, better and more just world, we can achieve development and peace and pave the way for the development of mankind based on solidarity, humanization of society and emancipation of man. I am convinced that contemporary science and universities can and must assume their fair share of responsibility for the sake of better future. As Federico Mayor, a former UNESCO director said: "We need univeristies that would try to develop people's capacity to think and to be personally responsible in the society whichthey live in and which they serve." (Major, 1991). Naturally, in the conditions of globalization, this responsibility must be linked to the ethics of the planetary era, which, as Edgar Morin, a distinguished French anthropologist and sociologist, put it, requires not only globalization of understanding, but also intellectual and moral solidarity of mankind (Moren, 1992).

\section{References}

1. Čomsky, N. (2016): Jer mi tako kažemo [Because we say so], Službeni glasnik. Beograd.

2. Jaspers, K., Ideja univerziteta [The Idea of the University], Plato, Beograd 2003.

3. Major, F., Sutra je uvek kasno [Tomorrow is always late], Jugoslovenska revija, Beograd 1991.

4. Mitrović, Lj., Univerzitet $i$ društvene promene [The University and social changes], Učiteljski fakultet, Vranje 2012.

5. Moren, E., Odgoj za budućnost [Education for the future], Eduka, Zagreb 1992.

6. Pečujlić, M., Univerzitet budućnosti [The university of the future], Beograd 1988.

7. Šaf, A., Kamo vodi taj put? [Where does this road lead?], Globus, Zagreb 1989. 


\section{Љубиша МИТРОВИЋ}

\section{СОЦИОЛОШКЕ МАРГИНАЛИЈЕ О ДЕОНТОЛОГИЈИ ПОЗИВА ПРОФЕСОРА ЕМЕРИТУСА У ЗАЈЕДНИЦИ НОМО ACADЕМICUS-A И САВРЕМЕНОМ ДРУШТВУ}

Резиме: За правог/истинског ствараоца, научника и револуционара, нема пензије. Они попут „старих“ храстова одолевају зубу времена све док траје у њима стваралачки ерос и прометејски етос позива. Њихову интелектуалну одисеју, тек привремено, прекида физичка смрт, а њихово дело тек на „решету времена“ показује праву/трајну вредност надживљавајући својим дометима своје ауторе. Мера њиховог стваралаштва је: колико оно служи унапређењу квалитета образовања и научног рада, универзитетске заједнице hото academicusa, подизағу његових иновационих потенцијала и колико умножава критичку интелектуалну моћ начије и човечанства.

У прилогу се разматрају социолошки, педагошки, научни и културолошки аспекти мисије позива професора емеритуса у савременој академској заједници. Искуство показује да су развијена друштва, универзитетске заједнице и корпоращије, отворене за ангажовање професора емеритуса и коришћење юиховог богатог педагошког и научно-истраживачког искуства, за разлику од неразвијених ауторитарних заједница, чије се политичке и менаиерске елите неодговорно понашају према потенцијалима припадника „треће генерацุије“. У раду се чини покушај сочиолошке класификације друштава према юиховом односу, према научним и педагошким иновацијама и интелектуалним потенцијалима професора емеритуса, као и ближе елаборације/ експликације њихове деонтолошке функиије у животу и раду савременог универзитета и савременог друштва. Аутор поентира свој рад: зрела и здрава друштва знања отворена су према иновацијским потенцијалима професора емеритуса и не уносе меру „годишњих доба“/старости као критеријум дискриминачије, већ стимулирају спорни спој/синтезу искуство и младости, у перманентном образовању homo academicusa.

Избор у највише звање професора емеритуса није само част већ и право и обавеза да се служи научној заједници, и научној култури и човечанству.

Кључне речи: Интелектуални капитал, људски ресур, иноващије, позив и функиије професора емеритуса.

Примљено: 5. 3. 2018. године.

Одобрено за штампу: 15. 6. 2018. године. 